\title{
BRPKM
}

Buletin Riset Psikologi dan Kesehatan Mental

http://e-journal.unair.ac.id/index.php/BRPKM

e-ISSN: 2776-1851

ARTIKEL PENELITIAN

\section{Gambaran Psychological Well-Being pada Pro-player Tim E-Sport Indonesia}

\author{
NAOMI MUTIARA JASMINE* \\ Fakultas Psikologi Universitas Airlangga
}

\begin{abstract}
ABSTRAK
Rutinitas pro-player yang cukup padat dapat menimbulkan dampak negatif pada pro-player dalam beberapa aspek. Kesehatan pro-player menjadi hal yang penting untuk diperhatikan demi mencapai dan mempertahankan kinerja yang maksimal, serta mengurangi risiko yang mungkin terjadi, baik dalam aspek fisik maupun mental. Dalam penulisan ini, penulis bertujuan untuk meneliti lebih lanjut dan mendalam mengenai psychological well-being pada pro-player. Penulisan ini menggunakan pendekatan kualitatif dengan metode studi kasus intrinsik dan pengumpulan data dilakukan melalui wawancara dengan pedoman umum. Partisipan penulisan berjumlah 2 orang pro-player tim E-Sport Indonesia yang telah aktif di bidang E-Sport Indonesia sebagai player lebih dari 2 tahun. Hasil dari penulisan ini menunjukkan bahwa kedua partisipan memiliki kondisi psychological well-being yang cukup berbeda. Salah satu partisipan memiliki tingkat psychological well-being yang cukup tinggi, menunjukkan bahwa seorang pro-player dapat memiliki kondisi psychological well-being yang baik meskipun menghabiskan waktu yang sangat banyak untuk bermain video game.
\end{abstract}

Kata kunci: e-sport, pro-player, psychological well-being

\begin{abstract}
The daily routine of pro-player can have a negative impact on themself in several aspects. Pro-players' health is important to pay attention to in order to achieve and maintain maximum performance, and to reduce risks that may occur, both in physical and mental aspects. In this study, the author aims to investigate further about the psychological well-being of pro-players. This research uses qualitative approach with intrinsic case study method and data collection is carried out through interviews. The participants consisted of 2 pro-players of Indonesian E-Sport teams who have been active in the Indonesian E-Sport field for more than 2 years. The result indicates that the two participants have quite different psychological well-being conditions. One of the participants had a fairly high level of psychological well-being, indicating that a pro-player can have a good state of psychological well-being despite spending a lot of time playing video games.
\end{abstract}

Keywords: e-sport, pro-player, psychological well-being

Buletin Penulisan Psikologi dan Kesehatan Mental (BRPKM), 2021, Vol. 1(2), 1357-1368

*Alamat korespondensi: Fakultas Psikologi Universitas Airlangga, Kampus B Universitas Airlangga Jalan

Airlangga 4-6 Surabaya 60286. Surel: naomi.mutiara.jasmine-2017@psikologi.unair.ac.id 
Naskah ini merupakan naskah dengan akses terbuka dibawah ketentuan the Creative Common Attribution License (CC-BY-4.0) (http://creativecommons.org/licenses/by/4.0), sehingga penggunaan, distribusi, reproduksi dalam media apapun atas artikel ini tidak dibatasi, selama sumber aslinya disitir dengan baik.

\section{PENDAHULUAN}

Bermain video game telah menjadi salah satu hiburan atau kegiatan rekreasi paling populer, tidak hanya di kalangan anak-anak dan remaja, tetapi juga di kalangan orang dewasa (Fitzgerald, 2020). Video game telah banyak berubah selama lima dekade terakhir (Bányai dkk., 2019). Menurut data yang didapat oleh Statista ("Video Games-Worldwide | Statista Market Forecast", 2021), jumlah pemain video game secara global mencapai 1,788 triliun di tahun 2019, dan di Indonesia sendiri pemain video game mencapai 55,66 juta. Berdasarkan data ini dapat dilihat bahwa peminat video game di Indonesia cukup banyak dan akan terus bertambah dari tahun ke tahun, mengingat faktanya bahwa video game mobile merupakan salah satu pendorong pertumbuhan pasar video game karena dapat diakses dengan mudah dan dimainkan di mana saja.

Keterampilan yang terlibat dalam bermain dan menguasai video game telah berkembang menjadi bentuk cabang olahraga baru yang dikenal dengan istilah "E-Sport" atau olahraga elektronik. E-Sport adalah area baru dalam budaya permainan, dan mulai menjadi salah satu bagian yang penting dan populer dari komunitas video game, terutama di kalangan remaja dan dewasa muda. Saat ini video game telah menjadi pilihan karir di dunia game kompetitif bagi sebagian pemain (Griffiths, 2017). Di Indonesia telah ada beberapa tim E-Sport besar yang sudah banyak memenangkan kompetisi nasional maupun internasional, antara lain EVOS, RRQ, BOOM, ONIC, dan Bigetron.

The International adalah turnamen Dota 2 yang diselenggarakan oleh Valve dengan hadiah tertinggi yang pernah diselenggarakan. Pada tahun 2019, total hadiah kejuaraan dunia Dota 2 ini adalah 34,3 juta dollar AS. Di Indonesia sendiri terdapat kompetisi E-Sport yang merupakan hasil kolaborasi antara Kantor Staf Presiden, KEMENPORA, KEMENKOMINFO, BEKRAF, IESPL, BCA, dan BliBli.com. Kompetisi ini diadakan oleh pemerintah sebagai wadah untuk menemukan dan membina pro-player di Indonesia agar dapat meraih prestasi di tingkat nasional maupun internasional. Melihat bagaimana E-Sport telah berkembang dan memiliki pendapatan sebesar, tidak heran jika semakin banyak generasi muda tertarik dan berminat untuk menjadi pemain profesional E-Sport, atau yang biasa disebut dengan istilah proplayer (professional player).

Ma dkk. (2013) tertarik pada kenyataan bahwa para pemain E-Sport berbeda dari para pemain biasa. Pemain E-Sport adalah pemain profesional yang bermain untuk kompetisi, bukan untuk bersenangsenang dan atau relaksasi, dan menganggap game sebagai pekerjaan mereka. Pemain biasa bermain untuk bersenang-senang dan rekreasi, dan untuk menghibur diri mereka sendiri (Ma dkk., 2013). Atlet E-Sport atau pro-player justru lebih serupa dengan atlet olahraga tradisional dalam banyak aspek. Persamaan yang ada di antara pro-player dengan atlet olahraga tradisional tentunya tidak dimiliki oleh pemain video game biasa.

Ada kesamaan fitur antara E-Sport dan olahraga tradisional, meskipun E-Sport tidak membutuhkan aktivitas fisik sebanyak olahraga tradisional, yaitu sama-sama mencakup chemistry tim, strategi, kompetisi, bakat, dan peningkatan (Crawford \& Gosling, 2009). Taylor (2012) juga menyoroti dalam bukunya bahwa aturan turnamen, sistem, permainan, penilaian, dan penyiaran dalam E-Sport dapat serupa dengan olahraga tradisional, dan pro-player dapat dibandingkan dengan atlet olahraga

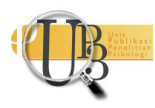


profesional (seperti dalam hal pelatihan, latihan, kondisi fisik dan mental atlet). Pro-player juga berlatih dengan pelatih seperti atlet olahraga tradisional (Jenny dkk., 2017). Infrastruktur E-Sport dapat dibandingkan dengan tim olahraga tradisional seperti sepak bola, hoki es, atau bola basket (Nagorsky \& Wiemeyer, 2020). Pro-player tidak hanya dibayar oleh sponsor, tetapi juga bekerja dengan organisasi dan klub E-Sport profesional. Selain itu, telah diumumkan bahwa E-Sport menjadi salah satu cabang olahraga resmi peraih medali di Asian Games 2022 (Putri, 2020).

Untuk mencapai dan mempertahankan tingkat kinerja yang maksimal, para pro-player harus terus berlatih dan meningkatkan atau mempertahankan keterampilan mereka. Dalam pelatihan, terdapat perbedaan antara olahraga profesional dan E-Sports profesional. Pelatihan atlet olahraga profesional didasarkan pada penulisan ilmiah yang sudah mapan, sedangkan pelatihan $E$-Sport belum sepenuhnya mencakup ilmu olahraga dikarenakan masih sedikit penulisan yang membahas tentang peningkatan keterampilan dan kinerja dalam E-Sport (Nagorsky \& Wiemeyer, 2020).

Game adalah stressor dan sama seperti jenis stres lainnya, terlalu banyak dapat menjadi berbahaya. Banyak pro-player percaya bahwa mereka harus bekerja keras untuk meningkatkan dan mencapai kinerja puncak, namun pendekatan ini tidak efisien dan dapat menyebabkan kinerja yang buruk dan masalah kesehatan (Himmelstein, 2019). Inilah mengapa periodisasi latihan juga dibutuhkan dalam $E$ Sport. Periodisasi sendiri adalah perencanaan sistematis dari rejimen pelatihan pemain untuk mencapai kesuksesan jangka panjang selagi mengurangi risiko cedera dan kelelahan (Himmelstein, 2019).

Himmelstein (2019) lebih lanjut menjelaskan bahwa tuntutan fisik dan mental dalam bermain video game serupa dengan yang ditemukan dalam olahraga tradisional, seperti detak jantung yang tinggi dan tingkat stres selama kompetisi. Sering bertanding dalam kompetisi, jam latihan yang panjang, perjalanan, dan keseimbangan dinamika tim dapat berbahaya dan dapat menghambat pertumbuhan pemain tanpa istirahat yang cukup. Terlalu banyak stres yang disebabkan karena terlalu banyak bermain game dan terlalu sedikit istirahat dapat menyebabkan kinerja yang buruk, cedera, dan burnout (kelelahan emosional, fisik, dan mental), yang tentunya tidak baik bagi kesehatan fisik maupun mental pro-player.

Berdasarkan wawancara yang dilakukan oleh tim Intel ("Kehidupan Gamer-Rutinitas Keseharian Gamer", n.d.), Lynnie "artStar" Noquez dari tim Dignitas (Amerika Utara) dan Cody Sun dari tim Clutch Gaming Academy (Amerika Utara) menjelaskan bahwa rutinitas sehari-hari mereka mencakup latihan tim terstruktur selama enam hingga delapan jam yang dilakukan lima hari seminggu, dan selalu dilengkapi dengan beberapa jam latihan mandiri di luar jam latihan rutin. Latihan rutin biasa dilakukan pada malam hari. Noquez juga menjelaskan bahwa seorang pro-player juga tetap harus berolahraga dan menjaga tubuhnya tetap fit, setidaknya rutin melakukan peregangan. Peregangan dianggapnya sangat penting untuk menghindari cedera pergelangan tangan, leher, dan bahu yang jadi sering terjadi karena terlalu lama duduk.

Langga dari tim ONIC (Indonesia) dalam wawancara dengan VOA (Wicaksana \& Widyastuti, 2019) menjelaskan bahwa latihan rutinnya biasa dimulai dari jam delapan malam hingga jam satu pagi. Mereka sudah terbiasa untuk tidur di pagi hari dan baru terbangun di siang hari. Setiap bulan para atlet juga mendapatkan gaji bulanan dan bonus turnamen dengan kisaran satu hingga lima puluh juta rupiah. Tidak hanya itu, Justin Widjaja selaku direktur manajer ONIC juga menjelaskan bahwa adanya menu latihan fisik selama satu hingga dua jam setiap minggunya untuk mengimbangi kesehatan fisik atletnya. Tim ONIC memiliki physical coach yang bertugas untuk membimbing para atletnya dalam meningkatkan ketahanan, fokus, dan mental. 
Seperti yang telah dipaparkan, kesehatan pro-player menjadi hal yang penting untuk diperhatikan demi mencapai dan mempertahankan kinerja yang maksimal, serta mengurangi risiko yang mungkin terjadi, baik dalam aspek kesehatan fisik maupun kesehatan mental. Dalam hal ini, penulis ingin berfokus pada kesehatan mental pro-player. Kesehatan mental adalah hal yang penting karena merupakan bagian penting dari kehidupan dan memengaruhi pikiran, perilaku, dan emosi. Menjadi sehat secara emosional dapat meningkatkan produktivitas dan efektivitas dalam kegiatan-kegiatan seperti pekerjaan, sekolah, atau pengasuhan. Hal ini memiliki peran penting dalam kesehatan suatu hubungan, dan memungkinkan untuk beradaptasi dengan perubahan dalam hidup dan mengatasi kesulitan dengan baik (Xiong, 2018).

Model psychological well-being oleh Ryff \& Keyes (1995) menegaskan bahwa kesejahteraan itu multidimensi, dan bukan hanya tentang kebahagiaan, atau emosi positif. Kehidupan yang baik adalah kehidupan yang seimbang dan utuh, melibatkan setiap aspek kesejahteraan yang berbeda. Ryff \& Keyes (1995) melandaskan prinsipnya dalam nichomachean ethics milik Aristoteles, dimana tujuan hidup bukanlah hanya tentang perasaan yang baik, melainkan tentang hidup dengan bajik atau bermoral. Huppert (2009) juga menyatakan bahwa orang-orang dengan psychological well-being yang tinggi lebih mungkin untuk hidup lebih sehat dan lebih lama, dan cenderung memiliki kualitas hidup yang lebih baik.

Penulisan mengenai tingkat kecanduan video game dan pemain video game (gamer) telah banyak dilakukan, namun penulisan mengenai psychological well-being pada pro-player masih jarang ditemukan, khususnya di Indonesia. Penulisan ini bertujuan untuk meneliti lebih lanjut dan mendalam mengenai psychological well-being pada pro-player. Penulis memutuskan untuk meneliti pro-player karena E-Sport sedang menjadi fenomena yang cukup besar dan menjadi perhatian masyarakat di Indonesia. Selain itu kesehatan mental pro-player Indonesia, khususnya dalam aspek psychological wellbeing, dirasa perlu mendapatkan perhatian lebih.

\section{E-Sport}

Merujuk pada video game kompetitif (profesional maupun amatir) yang sering dikoordinasi oleh liga, peringkat, dan turnamen, dan di mana para pemain biasanya berada dalam suatu tim atau organisasi olahraga lainnya yang disponsori oleh berbagai organisasi bisnis (Hamari \& Sjöblom, 2017). E-Sport berfokus pada kompetisi, yang dalam konteks ini mengarah pada adanya dua lawan (baik individu atau tim) yang bersaing dalam video game. Beberapa turnamen besar yang ada di Indonesia antara lain Mobile Legends Professional League (MPL), ESL National Championship, Piala Presiden, dan Indonesia E-Sports League (IEL).

\section{Pro-player}

Pemain profesional yang bermain untuk kompetisi, bukan untuk bersenang-senang dan atau relaksasi, dan menganggap game sebagai pekerjaan mereka (Ma dkk., 2013). Pro-player biasanya memiliki kontrak dan digaji oleh tim atau sponsor mereka, dan akan mendapatkan bonus tambahan ketika berhasil memenangkan turnamen. Berbeda dengan pemain video game yang biasa, mereka bermain untuk bersenang-senang dan rekreasi, dan untuk menghibur diri mereka sendiri. Umumnya latihan rutin dilaksanakan selama 6-8 jam sehari, dan dilaksanakan 5 kali dalam seminggu, namun jadwal tersebut dapat berubah ketika menjelang turnamen atau kejuaraan.

\section{Psychological Well-Being}

Kondisi di mana individu dapat mengevaluasi kehidupan diri sendiri dan masa lalunya secara positif, memiliki kesadaran akan pertumbuhan dan perkembangan yang berkelanjutan, kepercayaan bahwa

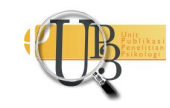


hidupnya bertujuan dan berarti, hubungan yang berkualitas dengan orang lain, kapasitas untuk mengelola kehidupan diri sendiri dan dunia sekitarnya secara efektif, dan kesadaran akan penentuan nasib diri sendiri (Ryff \& Keyes, 1995). Psychological well-being menurut Ryff \& Keyes (1955) memiliki 6 dimensi, yaitu self-acceptance, personal growth, purpose in life, positive relations with others, enviromental mastery, dan autonomy. Selain itu terdapat banyak faktor yang dapat mempengaruhi psychological well-being seseorang, antara lain usia, jenis kelamin, status sosial ekonomi, budaya, pendidikan, dan kesehatan.

\section{Desain Penulisan}

\section{METODE}

Pendekatan yang digunakan dalam penulisan ini adalah pendekatan kualitatif dengan metode studi kasus. Pendekatan ini dipilih karena memungkinkan penulis memahami secara utuh bagaimana partisipan berfungsi melalui pengumpulan informasi secara sistematis tentang individu, setting sosial, peristiwa, maupun suatu kelonpok (Berg, 2009). Jenis studi kasus yang digunakan dalam penulisan ini adalah studi kasus intrinsik, yang dipilih karena ketertarikan penulis pada suatu kasus karena kekhususan dan keunikannya.

\section{Partisipan}

Partisipan utama dalam penulisan ini adalah pro-player tim E-Sport Indonesia berjumlah 2 orang. Pemilihan partisipan dilakukan dengan teknik purposive sampling, di mana penulis menentukan partisipan berdasarkan pertimbangan dan tujuan tertentu (Moleong, 1989). Partisipan utama penulisan dipilih berdasarkan kriteria: (1) pro-player tim E-Sport Indonesia, (2) laki-laki atau perempuan, (3) telah aktif di bidang E-Sport Indonesia selama 2 tahun sebagai player. Kriteria tersebut dicantumkan dalam poster digital, yang kemudian disebarkan di beberapa media sosial. Individu yang memenuhi kriteria dan bersedia untuk terlibat dalam penulisan diarahkan untuk menghubungi penulis di akun media sosial yang tertera di poster digital. Selain menggunakan poster digital, penulis juga mencoba menghubungi beberapa pro-player yang memenuhi kriteria melalui media sosial. Setelah mendapatkan partisipan yang memenuhi semua kriteria, penulis memberikan informed consent dan membuat kesepakatan terkait jadwal pelaksanaan wawancara dengan partisipan.

\section{Strategi Pengumpulan Data}

Teknik pengumpulan data yang digunakan dalam penulisan ini adalah wawancara mendalam (in-depth interview) dengan pedoman umum. Tujuan dilakukannya wawancara adalah memberi gambaran rekonstruksi orang, kejadian, organisasi, perasaan, tuntutan, dan lain-lain; memproyeksikan kejadian di masa lalu dan harapan di masa mendatang; memverifikasi, memperluas, dan mengubah informasi yang diperoleh dari sumber lain (Moleong, 1989). Jenis pedoman wawancara yang digunakan adalah semistructured, di mana pedoman wawancara yang dibuat bersifat tidak kaku dan dapat dikembangkan sesuai dengan konteks selama proses wawancara.

Proses wawancara dilakukan sebanyak dua kali untuk tiap partisipan pada waktu yang telah disepakati oleh partisipan dan penulis. Wawancara pertama dilakukan melalui video call menggunakan Google Meet, dan wawancara kedua dilakukan melalui telepon. Penggalian data dilakukan secara online karena partisipan berlokasi di kota yang berbeda dengan penulis, bersamaan dengan terjadinya pandemi global

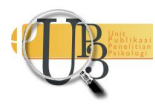


penyakit coronavirus (COVID-19) yang membatasi aktivitas sosial maupun berpergian. Selama proses wawancara berlangsung, penulis menggunakan perekam suara untuk merekam proses wawancara.

Teknik pemantapan kredibilitas penulisan yang digunakan dalam penulisan ini adalah member check. Member check adalah proses pengecekan data yang diperoleh penulis kepada pemberi data. Tujuan dari member check adalah agar informasi yang diperoleh dan akan digunakan dalam penulisan laporan sesuai dengan apa yang dimaksud sumber data atau informan (Sugiyono, 2008). Penulis melakukan member check ketika seluruh data dari hasil wawancara sudah lengkap, dengan tujuan untuk memastikan dan mengkonfirmasi ulang bahwa data yang didapat dari hasil wawancara adalah sesuai dengan apa yang dimaksud oleh partisipan.

\section{Analisis Data}

Data yang dihasilkan dari proses pengumpulan data adalah berupa catatan-catatan selama proses wawancara maupun rekaman suara yang kemudian diubah ke dalam bentuk transkrip (verbatim). Teknik analisis yang digunakan dalam penulisan ini adalah analisis tematik dengan pendekatan theory driven. Terdapat 6 tahapan dalam melakukan koding dengan pendekatan theory driven menurut Fereday \& Muir Cochrane (2006), yaitu: (1) membuat kode manual, (2) menguji reliabilitas pada kode, (3) meringkas data dan mengidentifikasi tema awal, (4) mengaplikasikan kode dan penambahan kode bila diperlukan, (5) menghubungkan setiap kode dan mengidentifikasi tema, dan (6) menguatkan temuan.

\section{HASIL PENELITIAN}

Gambaran psychological well-being pada pro-player dapat dilihat berdasarkan keenam dimensi psychological well-being dari informasi yang telah diberikan oleh kedua partisipan. Hasil temuan penulisan memperlihatkan adanya keragaman sikap dan perilaku yang ditunjukkan oleh masingmasing partisipan terkait dengan keenam dimensi psychological well-being dan dilatarbelakangi oleh faktor-faktor yang berbeda. Hasil penulisan disajikan dalam tabel berikut.

Tabel 1. Ringkasan Hasil Analisis Data

\begin{tabular}{|c|c|c|}
\hline Unit/Aspek & Partisipan RK & Partisipan CM \\
\hline Self-Acceptance & $\begin{array}{l}\text { 1. Partisipan dapat melihat kelebihan } \\
\text { dan kekurangan dalam dirinya, } \\
\text { partisipan ingin memperbaiki } \\
\text { kekurangannya agar tidak } \\
\text { merugikan dirinya maupun orang } \\
\text { lain. } \\
\text { 2. Partisipan dapat menerima masa } \\
\text { lalu, termasuk pengalaman yang } \\
\text { kurang menyenangkan dengan } \\
\text { baik, dan menjadikan masa lalunya } \\
\text { sebagai bahan pembelajaran dan } \\
\text { evaluasi diri. } \\
\text { 3. Partisipan dapat menerima dirinya } \\
\text { sendiri. }\end{array}$ & $\begin{array}{l}\text { 1. Partisipan dapat menerima } \\
\text { dirinya sendiri. Partisipan } \\
\text { mampu melihat dan mengakui } \\
\text { kelebihan dan kekurangan dalam } \\
\text { dirinya, namun sikap yang } \\
\text { ditunjukkan partisipan terhadap } \\
\text { dirinya tidak bisa disebut positif, } \\
\text { partisipan terkesan tidak dapat } \\
\text { menerima dirinya sepenuhnya. } \\
\text { 2. Partisipan tidak dapat menerima } \\
\text { masa lalunya dengan baik, } \\
\text { 3. partisipan mengaku bahwa } \\
\text { dirinya memiliki banyak } \\
\text { penyesalan di masa lalu yang }\end{array}$ \\
\hline
\end{tabular}




\begin{tabular}{|c|c|c|}
\hline Unit/Aspek & Partisipan RK & Partisipan CM \\
\hline Self-Acceptance & & $\begin{array}{l}\text { masih disesalinya sampai saat } \\
\text { ini. }\end{array}$ \\
\hline Autonomy & $\begin{array}{l}\text { 1. Partisipan mampu untuk tidak } \\
\text { terpengaruh dengan komentar } \\
\text { netizen, namun partisipan dapat } \\
\text { menerima pendapat orang lain } \\
\text { tentang dirinya untuk menjadi } \\
\text { bahan evaluasi bagi dirinya. } \\
\text { 2. Partisipan mampu menghadapi } \\
\text { tekanan dan ekspetasi orang lain } \\
\text { yang ia dapat ketika bertanding di } \\
\text { turnamen, dan dapat menerima } \\
\text { kekalahan dengan baik. } \\
\text { 3. Partisipan terlihat mampu } \\
\text { menganalisa dan menguraikan } \\
\text { permasalahan dengan baik, namun } \\
\text { tidak terlihat benar-benar mampu } \\
\text { untuk membuat keputusan sendiri } \\
\text { secara mandiri, karena partisipan } \\
\text { lebih menyukai diskusi dengan } \\
\text { orang lain sebelum membuat } \\
\text { keputusan. }\end{array}$ & $\begin{array}{l}\text { 1. Partisipan terlihat mampu } \\
\text { melawan tuntutan sosial di } \\
\text { sekitarnya, dan menunjukkan } \\
\text { bahwa ia memiliki kontrol dalam } \\
\text { perilakunya. } \\
\text { 2. } \begin{array}{l}\text { Partisipan memiliki standar } \\
\text { pribadi dalam menilai dirinya. }\end{array} \\
\text { 3. Partisipan juga terlihat mampu } \\
\text { untuk mengambil keputusan } \\
\text { secara mandiri. } \\
\text { 4. Partisipan menginginkan pujian } \\
\text { dan memerlukan pengakuan dari } \\
\text { orang lain atas pencapainnya } \\
\text { untuk membuatnya merasa } \\
\text { bahwa dirinya mampu mencapai } \\
\text { sesuatu dan diakui. }\end{array}$ \\
\hline $\begin{array}{c}\text { Positive } \\
\text { Relations with } \\
\text { Others }\end{array}$ & $\begin{array}{l}\text { 1. Partisipan mampu menjalin } \\
\text { hubungan baik dengan orang- } \\
\text { orang di sekitarnya. } \\
\text { 2. Partisipan memiliki hubungan } \\
\text { yang hangat dengan seluruh } \\
\text { anggota keluarganya. } \\
\text { 3. Partisipan memiliki empati yang } \\
\text { cukup tinggi dan mampu } \\
\text { memberikan afeksi pada orang } \\
\text { lain. } \\
\text { 4. Memiliki sosok yang dapat benar- } \\
\text { benar dipercaya. }\end{array}$ & $\begin{array}{l}\text { 1. Partisipan merupakan orang } \\
\text { yang mudah dan cepat akrab } \\
\text { dengan orang yang baru } \\
\text { dikenalnya. } \\
\text { 2. Partisipan memiliki hubungan } \\
\text { yang baik dengan teman-teman } \\
\text { di tim, orang-orang di lingkungan } \\
\text { tempat tinggalnya, dan } \\
\text { keluarganya. } \\
\text { 3. Partisipan tidak dapat } \\
\text { sepenuhnya terbuka dan percaya } \\
\text { dengan orang lain, bahkan } \\
\text { dengan orang yang paling ia } \\
\text { percaya, yaitu mamanya. }\end{array}$ \\
\hline $\begin{array}{l}\text { Environmental } \\
\text { Mastery }\end{array}$ & $\begin{array}{l}\text { 1. Partisipan terlihat memiliki } \\
\text { penguasaan dan kompetensi } \\
\text { dalam mengelola lingkungannya, } \\
\text { baik itu di lingkungan timnya } \\
\text { maupun di lingkungan } \\
\text { keluarganya. } \\
\text { 2. Partisipan mampu menciptakan } \\
\text { konteks yang sesuai dengan } \\
\text { kebutuhan. }\end{array}$ & $\begin{array}{l}\text { 1. Partisipan terlihat memiliki } \\
\text { penguasaan dan kompetensi } \\
\text { dalam mengelola lingkungannya, } \\
\text { terutama di lingkungan timnya. } \\
\text { 2. Partisipan mampu melihat } \\
\text { peluang dan menggunakan } \\
\text { kesempatan yang ada dengan } \\
\text { baik. }\end{array}$ \\
\hline
\end{tabular}




\begin{tabular}{|c|c|c|}
\hline Unit/Aspek & Partisipan RK & Partisipan CM \\
\hline $\begin{array}{c}\text { Environmental } \\
\text { Mastery }\end{array}$ & $\begin{array}{l}\text { 3. Partisipan kurang mampu } \\
\text { mengelola waktu kegiatan sehari- } \\
\text { seharinya dengan efektif, } \\
\text { khususnya sebelum partisipan } \\
\text { mengambil cuti kuliah dan masih } \\
\text { aktif berkuliah. }\end{array}$ & $\begin{array}{l}\text { 3. Partisipan tidak cukup mampu } \\
\text { dalam mengelola urusan sehari- } \\
\text { hari, khususnya dalam } \\
\text { perkuliahannya. }\end{array}$ \\
\hline Purpose in Life & $\begin{array}{l}\text { 1. Partisipan memiliki target dan } \\
\text { tujuan yang jelas untuk dirinya, ia } \\
\text { tidak berjalan tanpa arah dalam } \\
\text { hidupnya. } \\
\text { 2. Partisipan juga mampu melihat } \\
\text { bahwa masa lalu dan masa } \\
\text { sekarang memiliki arti. Baginya, } \\
\text { semua pengalaman yang ada } \\
\text { dalam hidupnya memiliki peran } \\
\text { dalam dirinya, dan merupakan } \\
\text { bahan pembelajaran untuk dirinya } \\
\text { menjadi lebih baik. }\end{array}$ & $\begin{array}{l}\text { 1. Partisipan memiliki kepercayaan } \\
\text { (beliefs) terkait hidup yang } \\
\text { bermakna, yang membuatnya } \\
\text { memiliki aims, goals, dan } \\
\text { objectives dalam hidupnya. } \\
\text { 2. Partisipan memiliki perencanaan } \\
\text { dan gambaran tentang masa } \\
\text { depannya, meskipun belum } \\
\text { sepenuhnya terperinci, ia tidak } \\
\text { berjalan tanpa arah dalam } \\
\text { hidupnya. }\end{array}$ \\
\hline $\begin{array}{l}\text { Personal } \\
\text { Growth }\end{array}$ & $\begin{array}{l}\text { 1. Partisipan menunjukkan keinginan } \\
\text { untuk selalu berkembang. Ia } \\
\text { seringkali menyebutkan } \\
\text { keinginannya untuk menjadi lebih } \\
\text { dan lebih baik lagi. } \\
\text { 2. Partisipan juga menyadari bahwa } \\
\text { tidak semua perubahan dalam } \\
\text { dirinya adalah hal yang baik. } \\
\text { Namun, partisipan dapat melihat } \\
\text { dirinya terus mengalami } \\
\text { perkembangan dan peningkatan } \\
\text { meskipun perlahan. } \\
\text { 3. Partisipan terlihat cukup mampu } \\
\text { untuk menyadari potensi yang } \\
\text { dimilikinya. } \\
\text { 4. Secara keseluruhan, partisipan } \\
\text { menunjukkan adanya } \\
\text { perkembangan yang } \\
\text { mencerminkan bahwa partisipan } \\
\text { lebih mengenal dirinya sendiri dan } \\
\text { memahami keterbatasannya. }\end{array}$ & $\begin{array}{l}\text { 1. Partisipan dapat melihat } \\
\text { peningkatan dan perkembangan } \\
\text { dalam dirinya dari waktu ke } \\
\text { waktu, khususnya sejak } \\
\text { partisipan berkarir di E-Sport. } \\
\text { 2. Partisipan terbuka dengan } \\
\text { pengalaman baru dan berani } \\
\text { mencoba hal baru. } \\
\text { 3. Partisipan yakin bahwa dirinya } \\
\text { memiliki potensi dapat menjadi } \\
\text { pro-player yang cukup hebat dan } \\
\text { pantas untuk bertanding di big } \\
\text { stage. } \\
\text { 4. Partisipan mengaku bahwa } \\
\text { dirinya cukup mengenal dirinya } \\
\text { sendiri, namun partisipan juga } \\
\text { mengaku bahwa dirinya masih } \\
\text { sering menyangkal perasaannya } \\
\text { sendiri. }\end{array}$ \\
\hline
\end{tabular}

\section{DISKUSI}

Hasil analisis data menunjukkan bahwa kedua partisipan memiliki kondisi psychological well-being yang berbeda. Partisipan RK memiliki tingkat psychological well-being yang cukup tinggi dibandingkan dengan Partisipan CM. Hal ini dikarenakan partisipan tersebut memenuhi dimensi self-acceptance, positive relations with others, dan personal growth dengan lebih baik dibandingkan dengan partisipan

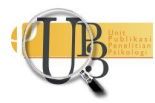


CM. Rendahnya dimensi self-acceptance pada partisipan CM sesuai dengan hasil penulisan yang dilakukan oleh Aditia Christianti (2016), yang di mana sebanyak 80\% partisipan dalam penulisan tersebut memiliki self-acceptance yang tergolong rendah dan sangat rendah.

Beberapa perbedaan yang terlihat pada kedua partisipan adalah partisipan RK memiliki sosok yang benar-benar bisa dipercaya, sedangkan partisipan CM tidak memiliki sosok yang bisa benar-benar dipercaya. Partisipan RK mampu untuk terbuka dengan orang lain dan memiliki empati yang tinggi, sedangkan partisipan CM kurang terbuka dengan orang lain dan memilih untuk tidak mempercayai siapapun, dan hanya percaya pada dirinya sendiri. Selain itu, perbedaan yang paling menonjol ada pada dimensi self-acceptance, di mana partisipan RK dapat menerima diri sendiri dan masa lalu dengan baik, serta menunjukkan sikap yang positif terhadap diri sendiri. Sedangkan partisipan CM tidak dapat menerima diri sendiri dan masa lalunya dengan baik.

Namun juga terdapat beberapa persamaan yang terlihat pada kedua partisipan, antara lain bagaimana kedua partisipan memiliki kesulitan dalam mengelola urusan sehari-hari, khususnya pada partisipan CM yang masih menjalani perkuliahan. Kedua partisipan juga memiliki aim, goals, dan objectives yang jelas, serta memiliki arah dalam hidup mereka. Kedua partisipan juga mampu menjalin hubungan dengan orang-orang di sekitarnya dengan baik. Dari persamaan yang ada, terlihat bahwa kedua partisipan memenuhi dimensi purpose in life dengan baik.

Kocadağ (2020) menyebutkan bahwa bekerja di bidang yang disukai memungkinkan dapat memotivasi dan mempengaruhi kesejahteraan psikologis secara positif, tergantung pada kepribadian masingmasing individu, namun hal tersebut tidak berlaku dalam pekerjaan yang melibatkan bermain video game, kesejahteraan psikologis akan tetap menurun seiring dengan banyaknya jam untuk bermain video game yang terus bertambah terlepas dari berhasil menghasilkan uang yang banyak atau tidak. Namun kondisi psychological well-being yang tergolong cukup tinggi pada partisipan RK menunjukkan bahwa seorang pro-player dapat memiliki kondisi psychological well-being yang baik meskipun sudah cukup lama berkarir di bidang E-Sport dan menghabiskan waktu yang sangat banyak untuk bermain video game, dan menunjukkan bahwa kepribadian memiliki pengaruh terhadap psychological well-being pada pro-player.

Dalam penulisan yang dilakukan oleh DiFrancisco-Donoghue dkk. (2019), disebutkan bahwa banyak pro-player menderita masalah psikologis dan fisik karena durasi waktu bermain yang cukup ekstrim. Namun permasalahan tersebut tampaknya tidak terlalu dialami oleh partisipan RK, khususnya pada aspek fisik, karena partisipan menggunakan waktu luangnya dengan pergi ke gym untuk berolahraga.

Hallmann dan Giel (2018) menyebutkan bahwa di banyak kompetisi, pro-player juga dihadapkan dengan tekanan fisiologis dan psikologis, hal ini juga disebutkan oleh partisipan RK bahwa dirinya merasakan tekanan ketika bertanding di turnamen yang dilaksanakan secara langsung, khususnya dari penonton, yang di mana memberikan lebih banyak tekanan untuk harus menang. Kedua partisipan juga menyebutkan bahwa tekanan juga sering muncul dari netizen di media sosial, seperti yang disebutkan oleh Smith dkk. (2019) bahwa stresor eksternal dapat berasal dari audiens yang dapat terbentuk pada tingkat yang berbeda-beda, seperti diintimidasi di media sosial. Namun di sisi baiknya, kedua partisipan dapat menghadapi tekanan ini dengan baik.

\section{SIMPULAN}

Masing-masing partisipan memiliki kondisi psychological well-being yang cukup berbeda dikarenakan setiap partisipan memiliki kepribadian dan pengalaman hidup yang berbeda, yang di mana 
menimbulkan dampak atau efek yang berbeda bagi tiap partisipan. Sehingga kondisi psychological wellbeing seorang pro-player akan berbeda dengan pro-player lainnya. Satu-satunya dimensi yang dapat dipenuhi oleh kedua partisipan dengan baik adalah dimensi purpose in life. Salah satu partisipan menunjukkan tingkat psychological well-being yang cukup tinggi dibandingkan dengan partisipan lainnya. Hal ini dikarenakan partisipan tersebut memenuhi dimensi self-acceptance, positive relations with others, dan personal growth dengan lebih baik dibandingkan dengan partisipan lainnya. Dengan begitu, hal ini menunjukkan bahwa seorang pro-player dapat memiliki kondisi psychological well-being yang baik meskipun sudah cukup lama berkarir di bidang E-Sport dan menghabiskan waktu yang sangat banyak untuk bermain video game.

Bagi penulisan selanjutnya, diharapkan dapat menggunakan metode yang berbeda dan lebih mendalami faktor-faktor yang dapat mempengaruhi psychological well-being pada pro-player. Bagi pro-player dengan psychological well-being yang cukup rendah diharapkan dapat mencoba untuk menerapkan mindfullness, melatih forgiveness, dan lebih membiasakan diri untuk mengekspresikan rasa bersyukur. Pihak management E-Sport juga diharapkan dapat lebih memperhatikan aspek psikologis para player dan bekerja sama dengan psikolog untuk memantau kesehatan mental para player, serta dapat memberikan pendampingan bagi player yang membutuhkan dukungan psikologis.

\section{UCAPAN TERIMAKASIH}

Penyusunan karya ini tidak terlepas dari masukan, bantuan, serta dukungan dari beberapa pihak. Terima kasih kepada Prof. Suryanto dan Bapak Ahmad Chusairi yang telah memberikan masukan yang sangat membantu, serta kepada kedua partisipan yang telah meluangkan waktunya di sela-sela jadwal latihan yang padat dan melelahkan.

\section{DEKLARASI POTENSI TERJADINYA KONFLIK KEPENTINGAN}

Naomi Mutiara Jasmine tidak bekerja, menjadi konsultan, memiliki saham, atau menerima dana dari perusahaan atau organisasi manapun yang mungkin akan mengambil untung dari diterbitkannya naskah ini.

\section{PUSTAKA ACUAN}

Bányai, F., Griffiths, M. D., Király, O., \& Demetrovics, Z. (2019). The Psychology of Esports: A Systematic Literature Review. Journal of Gambling Studies, 35(2), 351-365. https://doi.org/10.1007/s10899-018-9763-1

Berg, B. L. (2009). Qualitative research methods for the social sciences (7th ed). Allyn \& Bacon.

Christianti, A., Nanik, N., \& Setiono, V. (2016). STUDI DESKRIPTIF: PSYCHOLOGICAL WELL BEING PADA REMAJA YANG KECANDUAN BERMAIN GAME ONLINE DI SURABAYA. CALYPTRA, 5(1), 1-12.

Crawford, G., \& Gosling, V. (2009). More than a Game: Sports-Themed Video Games and Player Narratives. https://doi.org/10.1123/ssj.26.1.50

DiFrancisco-Donoghue, J., Balentine, J., Schmidt, G., \& Zwibel, H. (2019). Managing the health of the eSport athlete: An integrated health management model. BMJ Open Sport \& Exercise Medicine, 5(1), e000467. https://doi.org/10.1136/bmjsem-2018-000467

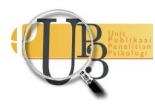


Fereday, J., \& Muir-Cochrane, E. (2006). Demonstrating Rigor Using Thematic Analysis: A Hybrid Approach of Inductive and Deductive Coding and Theme Development. International Journal of Qualitative Methods, 5(1), 80-92. https://doi.org/10.1177/160940690600500107

Fitzgerald, D. (2020). 2020 Essential Facts About the Video Game Industry. Entertainment Software Association. https://www.theesa.com/resource/2020-essential-facts/

Griffiths, M. (2017). The psychosocial impact of professional gambling, professional video gaming, and eSports. Casino and Gaming International, 28, 59-63.

Hallmann, K., \& Giel, T. (2018). ESports - Competitive sports or recreational activity? Sport Management Review, 21(1), 14-20.

Hamari, J., \& Sjöblom, M. (2017). What is eSports and why do people watch it? Internet Research, 27(2), 211-232. https://doi.org/10.1108/IntR-04-2016-0085

Himmelstein, D. (2019, March 11). Periodization in Esports. Training Room. https://www.acer.com/ac/en/US/content/training-room/article/periodization-in-esports

Huppert, F. A. (2009). Psychological Well-being: Evidence Regarding its Causes and Consequences†. Applied Psychology: Health and Well-Being, 1(2), 137-164. https://doi.org/10.1111/j.17580854.2009.01008.x

Jenny, S. E., Manning, R. D., Keiper, M. C., \& Olrich, T. W. (2017). Virtual(ly) Athletes: Where eSports Fit Within the Definition of "Sport". Quest, 69(1), 1-18. https://doi.org/10.1080/00336297.2016.1144517

Kehidupan Gamer-Rutinitas Keseharian Gamer. (n.d.). Intel. Retrieved 25 July 2021, from https://www.intel.com/content/www/id/id/gaming/resources/gamer-life.html

Kocadağ, M. (2020). An eSport research: Psychological well-being differences of teenagers in terms of several variables. 1, 31-39.

Ma, H., Wu, Y., \& Wu, X. (2013). Research on Essential Difference of E-Sport and Online Game. In W. Du (Ed.), Informatics and Management Science $V$ (Vol. 208, pp. 615-621). Springer London. https://doi.org/10.1007/978-1-4471-4796-1_79

Moleong, L. J. (1989). Metologi penulisan kualitatif. PT Remaja Rosdakarya.

Nagorsky, E., \& Wiemeyer, J. (2020). The structure of performance and training in esports. PLOS ONE, 15(8), e0237584. https://doi.org/10.1371/journal.pone.0237584

Putri, G. (2020, December 21). E-sport Jadi Cabang Olahraga Resmi di Asian Games 2022. Kompas. https://tekno.kompas.com/read/2020/12/21/15280027/e-sport-jadi-cabang-olahragaresmi-di-asian-games-2022

Ryff, C. D., \& Keyes, C. L. (1995). The structure of psychological well-being revisited. Journal of Personality and Social Psychology, 69(4), 719-727. https://doi.org/10.1037//00223514.69.4.719

Smith, M. J., Birch, P., \& Bright, D. (2019). Identifying Stressors and Coping Strategies of Elite Esports Competitors. International Journal of Gaming and Computer-Mediated Simulations, 11, 22-39. https://doi.org/10.4018/IJGCMS.2019040102

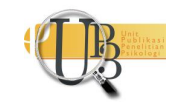


Sugiyono. (2008). Metode penulisan pendidikan: (Pendekatan kuantitatif, kualitatif dan $R \&$ D). Alfabeta.

Taylor, T. L. (2012). Raising the Stakes: E-Sports and the Professionalization of Computer Gaming. MIT Press.

Video Games-Worldwide / Statista Market Forecast. (2021). Statista. https://www.statista.com/outlook/dmo/digital-media/video-games/worldwide

Wicaksana, R., \& Widyastuti, D. (2019, September 26). Kehidupan Atlet "Video Games": Begadang hingga Penghasilan Puluhan Juta. VOA Indonesia. https://www.voaindonesia.com/a/kehidupan-atletvideo-games-begadang-hingga-penghasilan-puluhan-juta-/5099309.html

Xiong, G. (2018, October 6). Why It's Important to Care for Your Mental Health. Doctor On Demand. https://blog.doctorondemand.com/why-its-important-to-care-for-your-mental-health834c8670b889 